\title{
Four Centuries Evolution of Theoretical Thought on the Right to Master by the State in Indosesia
}

\author{
Subadi \\ Acosiate Profesor of Faculty of Law Merdeka University of Madiun, Indonesia \\ 79 Serayu Street, Madiun 63133, Indonesia
}

\begin{abstract}
The research financed by Directorate of Research and Community Service, Ministry of Research Technology and Higher Education, Fiscal Years 2018.
\end{abstract}

\section{Abstract}

The earth, water and natural resources contained in it controlled by the state and used for the greatest prosperity of the people as stipulated in Article 33 paragraph 3 of the 1945 Constitution, which is often referred to as the right of master by the State. As a concept, theory, principle, philosophy, dogtrin and ideology of work, the right to control by the State, it is the result of the evolution of very long theoretical thinking (more than four centuries). It is exactly the result of the interaction between Dutch colonial law and customary law (traditional Javanese) for 3.5 (three and a half) centuries of colonialism and the result of theoretical thinking of almost 75 (seventy five) years in the independence period. Therefore a science and a statutory regulation the right to control by the State has continued to develop.

Keywords:evolution, theoretical thought, rights to master, state, Indonesia

DOI: $10.7176 / \mathrm{JLPG} / 84-05$

Publication date: April $30^{\text {th }} 2019$

\section{Introduction}

Mastery over the earth, water and natural resources contained in it, for more than 3.5 (three and a half) centuries of colonialism has been taken advantage not for the benefit of Indonesian nation and almost 75 (seventy five) years of independence have not been able to realize how much possibelity for people's prosperity.

The desire and hope of the founding fathers, Is that the proclamation of independence achieved must bring great changes to the Indonesian nation, namely the desire to immediately realize a just and prosperous society, as mandated in the formulation of the fourth paragraph of the 1945 Constitution. It must make major changes in terms of mastery and use of natural resources by stipulating the "ideology of the right to control the state" as stipulated in Article 33 paragraph 3 of the 1945 Constitution which states that; "The earth, water and natural resources contained in it are controlled by the State and are used for the greatest prosperity of the people".

As stated in the ideological constitution regarding "the right to control the state" and "used for the greatest prosperity of the people", it is desirable that all laws and regulations below must reflect and constitute the application of legal ideas or ideals contained in Article 33 paragraph 3 of the 1945 Constitution. In other words, it must be a working ideology, in the mastery and management of the earth, water and natural resources contained in it.

Furthermore, the journey of the state's right of control for the greatest prosperity of the people ", is still often questioned and often debated or in other words still not in the final or supreme position, both in the text, context and contextualization. The right to control the state is good as a thought; concepts, theories, legal principles, for almost 75 (seventy five) years, there has never been an evaluation or testing of their validity. Likewise, as an ideology and a program of rights to control by the state, it has never been tested for its effectiveness in achieving the greatest prosperity of the people and this must be believed that there must be something wrong or something wrong.

\section{Colonial Period (Before Independence)}

\subsection{The Right to Dominate the State According to Customary Law (Javanese Traditional)}

The concept of state control in Indonesia is believed to originate from the traditional Javanese concept or Javanese customary law. In the traditional Javanese kingdom, the Javanese kings were the center of statehood and the king was absolutely the sole owner of the land, in the sense that theoretically he was the one who had the upper hand or who controlled all the land. ${ }^{1}$ As for their own needs and financing their activities, the princes and priyayi are given "sat" (apanage) or "land pay" and this residence will be returned to the king, when he has died or been fired, unless his heirs will be reinstated and it depends on the king. The understanding of ownership by the king over all the land and its means of use, is to prevent the growth of the noble rulers of the land. The views of the Javanese elite over land ownership are ambiguous or can be said no, no salaries or salaries are never mentioned in terms of

\footnotetext{
${ }^{1}$ Onghokham, (1984), Perubahan Sosial di Madiun Selama Abad XIX: Pajak dan Pengaruhnya Terhadap Penguasaan Tanah (Dalam Dua Abad Penguasaan Tanah; Pola Penguasaan Tanah di Jawa dari Masa ke Masa), PT. Gramedia, Jakarta, P. 3.
} 
hectares or acre, but according to their population (counts). In short, the wealth of the Javanese elite is not measured by how much it controls the land, but is measured by how much they control the number or population and this is a picture of strength and rebellion. ${ }^{1}$

This fact is different from the king and the elite who indirectly control the land, so that far from the factor of production, the farmers who directly control and cultivate the land are called "sikep". These "sikep" can own land through giving the king directly or through "priyayi". The king can order someone from the village head to prepare energy and donations of rice from the Sikep, namely by forming three new cops taken from the village. Therefore is an inseparable relationship between the Sikep and the kings and priyayi. The relationship between priyayi and peasants farmers, according to Javanese terms, is described as the "kawulo-gusti" relationship which, according to modern terms, is translated as "patron-client" (patron-client). ${ }^{2}$

Based on this description, there are at least two ways to obtain land, namely the Sikep farmers are given land on the condition that the king can use services, labor, and donations, then on the same principle as land given to priyayi, namely as salaries in lieu of wages for energy. The next development of these gestures can extend the land of his royal giving, with the help of his passage led by a gesture to open a new land which is ultimately known as the "land-foundation" or "land of inheritance" that can be left to his heirs. Anyone allowed to open the wild (empty), open the forest, he is permitted to own land (erfelijk individueel bezitsrecht), especially for areas of East Java, Central Java and West Java. ${ }^{3}$

Based on these thoughts it can be believed that the emergence of the original term for "belonging to hereditary individuals" is usually referred to as "yasa" or "yoso" which according to Javanese etymology means "everything obtained from individual businesses that converts wild land into cultivated land".On the side "just owning (darbe) or making it own property (confessed)".4

Apart from the tenure system applied in the traditional kingdom, there is still a system of land tenure according to customary law. The concept of land tenure in this system is based on communal rights, namely the rights of the legal community as a unit that has the authority to tie it in and out. Within the scope of these customary rights there are individual rights to land, namely rights born due to intensive control over a piece of vacant land. ${ }^{5}$

Based on two facts, namely the existence of communal land and individuals, the relationship between customary rights (owned by the legal community as a whole) and individual rights is created, that relationship is flexible. The stronger the individual's rights to land, the weaker the power of customary rights to the land. On the contrary, the weaker individual rights, the stronger the power of customary rights applies. ${ }^{6}$

So this individual rights will disappear and the land will return to the power of customary rights if the land is abandoned / becomes thicket or the forest returns. This customary right applies to binding into; first the alliance and its members have the right to withdraw from the land and everything that grows and lives on that land, establish dwellings, herd livestock, collect food ingredients, hunt and fish.;.Second; still limited individual rights in the community rights (ulayat) third, the alliance can establish land for public purposes, for example for hunting, cattle farming together, mosque and school grounds, for land title (crooked) as a gift to the dignitaries of the community. Customary rights apply and bind to the outside; the prohibition of outsiders from withdrawing profits from the land applies except with permission and after recognitie. Likewise outsiders are prohibited from owning individual land on agricultural land. ${ }^{7}$

\subsection{Mastery RightsAccording to Agrarische Wet 1870}

In accordance with political developments in the Netherlands, namely in 1870 which turned to liberal politics, then in that year agrarian law was issued which we know as Agrarische Wet 1870, (Staatblad No.55, 1870) promulgated on April 9, 1870 based on (hereinafter abbreviated) AW 1870). ${ }^{8}$

The issuance of AW 1870 began with the submission of an agrarian law draft by the de Waal Colony Minister which was motivated by the insistence of large private capital owners through the liberal groups in parliament. The purpose of the issuance of AW 1870 was none other than to open up the possibility for large private investors to use freely and exploitatively the lands in the colonies of the Dutch East Indies. In the era of the implementation of the cultuurstelsel politics, there had been a monopoly by the government and the owners of private capital could

\footnotetext{
${ }^{1}$ Erman Rajaguguk, (1995), Hukum Agraria Pola Penguasaan tanah dan Kebutuhan Hidup, Cadra Pratama, Jakarta., P. 8.

${ }^{2}$ Acmad Sodiki, (1993), Penataan Pemilikan Hak Atas Tanah di Daerah Perkebunan Kabupaten Malang (Studi tentang Dinamika Hukum), Desertasi, Tidak diterbitkan, Malang, P. 17

${ }^{3}$ Ibid,.P. 10 .

${ }^{4}$ Ibid., P. 15-16.

${ }^{5}$ Ibid.,P. 18.

${ }^{6}$ Boedi Harsono, Hukum Agraria Indonesia Himpunan Peraturan- Peraturan Hukum Tanah, Djambatan, Jakarta, P. 66.

${ }^{7}$ R. Van Dijk, (terjemahan) Suhardi, (1964), Pengantar Hukum Adat Indonesia, Bandung, P. 12.

${ }^{8}$ Boedi Harsono, (1995), Hukum Agraria Indonesia; Sejarah Penyusunan Undang-Undang Pokok Agraria, Isi dan Pelaksanaannya, Jilid I Hukum Tanah Nasional. cet. vi, Djambatan, Jakarta, P.31-33. See too Moh. Mahfud. MD, Karakter Produk Hukum Zaman Kolonial (Studi Tentang Politik dan Karakter Produk Hukum Pada Zaman Penjajahan di Indonesia), UII Press, Yogyakarta, 1997, P. 70-71, compare with Soetandyo Wignyosoebroto, (1995) Dari Hukum Kolonial Ke Hukum Nasional, Rajawali Press, Jakarta, P. 88.
} 
not take part in the exploration, except that they already had their own eigendom rights. ${ }^{1}$

In line with the emergence of liberalism in the Netherlands, the bourgeoisie, the owner of large capital, demanded that he was replaced with free competition based on the conception of liberal-capitalism. This is where the attraction between the government and the bourgeoisie takes place, but in fact the aim is the same, namely to extract and drain Indonesia's wealth, while the difference lies only in those who will enjoy the results of exploitation. $^{2}$

As one of the implementing regulations of AW 1870 is Koninklijk Besluit which is famous for Agrarische Besluit (abbreviated AB), which was promulgated by S.1870 No.118. This AB is only applied in Java and Madura, then the original dominance statement is also only applies in Java and Madura. In Article 1 AB contains an important provision, namely; "Domeinverklaring" (domein statement) which states that: "By not reducing the entry into force of the provisions in paragraphs 2 and 3 of Agrarische Wet. So it is maintained by principle, that all land that other people cannot prove, that the land is its eigendom land, is the land of the country". 3

The domein statement stipulated in article $1 \mathrm{AB}$, is actually not new or pre-existing, because it has been regulated in articles 519 and $520 \mathrm{BW}$, the words "maintained the principle ..." are used in AB. This principle is motivated by the assumption that only landowners are authorized to give erfpacht rights, opstal rights and others. In connection with the implementation of the AW order, to give rights to employers, it is deemed necessary to state that the land in question is owned by the state. Thus in the granting of these rights the state does not act as a ruler but as the civil owner. Likewise in the granting of eigendom rights, the state does not give eigendom rights to the applicant, but the eigendom of the country is transferred to the applicant with the price payment to the state. ${ }^{4}$

Domein Negara means eigendom state or state-owned, in other words on the basis of the domeinverklaring, the Dutch East Indies government can be the holder of eigendom rights to all no-man's land or lands which the population cannot prove to be eigendom rights. Therefore, every person or legal entity that has litigation with the state insofar as it is related to land ownership, he is obliged to prove that the disputed land belongs to him. Dominic's statement was opposed by Van Vollenhoven, because it was considered to have urged people's rights and allowed public land to be given to foreigners. Furthermore, it is also argued that the real state does not need a domestic principle because it is immediately based on its duties and its family has full power to regulate everything from living together for the public interest.. ${ }^{5}$

If you pay attention to specific legal ethical factors and factors, the needs and interests of the people of Indonesia, the principle of dominion can be highlighted from the following: 1) The reasons for the Dutch East Indies government did not contain elements that were channeled in Indonesian special law ethics, but based on , while the element of nature, populist, social justice and nationality does not exist; 2) Domestic principles only aim to benefit foreigners and mere administrative needs; 3) If measured by circumstances, needs and interests, it turns out that the community does not get attention, except (maybe) the will to return private land.The definition of state land turned out that finally the Dutch East Indies government made its own interpretation that what was included in the definition of state land (dominion) was: 1) All land which is not eigendom land and not agrarian eigendom as long as it is under direct government; 2) All land that is not eigendom according to BW; 3) All land that is not eigendom and not land owned by the people who are free from the rights of the people; 4) All land that is not eigendom land, not agrarian land eigendom and not land owned by the people, both those who have and who are not free from the customary rights environment. ${ }^{6}$

The problem of the official statement does not reduce the entry into force of AW 1870, but in the prevailing practice is the interpretation of the Dutch East Indies government. Boedi Harsono argues through his writing that "In connection with that, the lands owned by the people with property rights, business rights and others, are also lands that are abused by customary law communities with what is called customary rights, all are state lands".?

This fact was used as an excuse by Van Vollenhoven against "Domeinverklaring" which turned out in practice to have urged the rights of the people that Boedi Harsono could not be understood by the people and even contradicted people's legal awareness. After the law was issued, finally Indonesia, especially Java, had become a large plantation area. Thus, it is not wrong if agarian law (AW 1870 and AB 1870) is more appropriately referred to as investment law rather than a policy in the land sector. ${ }^{8}$

\footnotetext{
Ibid.

${ }^{2}$ Sartono Kartodirdjo, (1987), Pengantar Sejarah Indonesia Baru; Sejarah Pergerakan Nasional, PT. Gramedia, Jakarta, P. 22.

Boedi Harsono, Op.cit, P. 37

${ }^{4}$ Ibid, P. 39.

${ }^{5}$ Imam Sutiknyo, (1987), Proses Terjadinya UUPA, Gajah Mada University Press, Yogyakarta, P. 34-36.; compare with Mahfud MD., Karakter Produk Hukum Zaman Kolonial............. Op. cit, P. 75.

${ }^{6}$ Ibid, P. 30-31.

${ }^{7}$ Soetando Wignyosoebroto, (1995), Dari Hukum Kolonialke Hukum Nasional (Dinamika Sosial Politik Dalam Perkembangan Hukum Di Indonesia), Raja Grafindo Persada, Jakarta, P. 91. Konsep Domein yang dirujuk Agrarisch Wet, ....bahwa tanah-tanah yang tidak digarap penduduk serta merta haruslah dipandang sebagai bagian dari domein, kawasan kekuasaan atau tanah milik negara.

${ }^{8}$ Charles Himawan, The Role of Law in Indonesia's Plantation Invesment, Paper Presented at "Solely to be used During the $3^{\text {rd }}$ Meeting of Joint Working Party Between Indonesia and United Kingdom, Oktober $7^{\text {th }} 1981$, Jakarta., P. 8.
} 
Furthermore, when viewed in terms of the objectives for investment in the large private sector in the Netherlands East Indies, it was very successful, while other objectives to provide protection for land rights belonging to the indigenous groups actually failed miserably. This was due to the fact that residents who were originally farmers had lost their lands, and later became laborers on plantations owned by large entrepreneurs. ${ }^{1}$

\section{Period After Independence}

\subsection{Before UUPA 1960}

The concept of the rationale for "the right to control the state for the greatest prosperity of the people" in Indonesia as stipulated in Article 33 paragraph 2 and paragraph 3 of the 1945 Constitution, begins with the thoughts expressed in the session of the Investigators of Preparations for Indonesian Independence (BPUPKI ), and the Preparatory Committee for Indonesian Independence (PPKI) on 29 May to 19 August 1945. At the time it was presented several theoretical ideas or basic concepts about the right to control the state, namely:

- Moh. Hatta in his speech before the BPUPKI session stated that; "Land must be seen as a means or factor of production for mutual prosperity, not for the benefit of individuals, which in turn can encourage the accumulation of land tenure in a group or a group of people who ultimately oppress other community groups. He further emphasized that; no one should make land a tool to suppress other community groups. "One of the basic concepts raised by Moh. Hatta is basically land that belongs to the people of Indonesia and the state is the incarnation of the people who have the right to regulate their use in order to pursue common prosperity. ${ }^{2}$

- Soepomo in his address to BPUPKI on May 31, 1945, stated that: in building an integralistic state based on unity, the problem of relations between the state and the economy will be used by the system of "state socialism" (staatssocialism). Important companies will be managed by their own country, but at what level the state will determine where and at what time and what company will be held by the central government or local government ......... jungle base companies must be managed by the country itself. Likewise about the land, in essence the country that controls all the land. The important mines for the country will be managed by the country itself. Seeing the nature of Indonesian society as an agricultural society, then by itself agricultural land becomes a living field of the peasants and the state must maintain, so that agricultural land remains held by the peasants. ${ }^{3}$

- Muhammad Hasan, after the formation of the 1945 Constitution and the successful formulation of Article 33 paragraph 2 and paragraph 3, it is planned that, within the next 10 (ten) years, it is expected to be able to make laws regarding natural resources, but this cannot be realized. At the time when the law was actively struggling, there was an important event, namely, in 1950 where it was estimated that it was able to formulate a law on natural resources, in the Republic of Indonesia House a person named Muhammad Hasan, the former Governor of Sumatra had submitted a resolution to prohibit the issuance of mining concessions, because this is considered contrary to Article 33 of the 1945 Constitution. The resolution has been accepted by acclamation in the DPR RI, so since then the concession will no longer apply in the RIS Government and in the Indonesian Government. This resolution, allegedly was the first event of the implementation and implementation of "state control over mining resources".

- Notonegoro, within the framework of 10 (ten) years, namely at the time of the enactment of the 1950 Constitution, Notonegoro expressed his thoughts in drafting the basic concepts of legal politics and agrarian development in Indonesia, and these concepts included; concerning the right to control the state over land and the relationship of individual and collective rights. Furthermore, in its conception around the right to control the land by the state which regarding the smallest state constitutional law community can be used to continue the relationship between the village and the land, give village authority over the land, inheritance and so on. ${ }^{4}$ The right to control by the state on land according to Notonegoro, as the highest right to land in Indonesia whose subject is the country and this subject cannot be replaced, because if the right to control the land can be released then it means that state power over land is also reduced. The statements about land as belonging to all the people or the common land eventually developed into a concept of "the rights of the nation" which had the duty and authority to regulate and manage the common land for the greatest prosperity of the people. ${ }^{5}$ The concept of "national rights" which includes the duties of public law, its implementation was assigned to the state of the Republic of Indonesia, as the highest organization of national power, finally standardized through express statements in the provisions of Article 33 paragraph 3 of the 1945 Constitution, which states that: "Earth, water and wealth the nature contained in it is controlled by the state and used for the greatest prosperity of the

\footnotetext{
${ }^{1}$ Ibid, P. 9.

${ }^{2}$ Moh. Hatta, lebih lanjut menjelaskan bahwa tanah perkebunanpun yang sebenarnya milik rakyat, seharusnya dikuasai oleh rakyat dalam bentuk koperasi, tidak dikuasai oleh seseorang pemilik perkebunan.

${ }^{5}$ Boedi Harsono, Menuju Penyempurnaan Hukum ........ Op.Cit, P. 47.
} 
people ". 1

Looking at the provisions stipulated in Article 33 paragraph 3 of this 1945 Constitution, it has been shown that; 1) the state controls the earth, water and natural resources contained therein; 2) The earth, water and natural resources contained therein are used for the greatest prosperity of the people. Based on the formulation, it can give clues about how to think (denken), will (willen), and act or act (hendelsen) over; earth, water and natural resources contained in it. This is where the right of control by the state is located as an ideology of work (idealized working), a basic guideline and at the same time a program that is applied in various laws. ${ }^{2}$

The statement of the concept of national rights as the highest tenure right over common land, is eternal and at the same time constitutes the mother of other tenure rights over land, finally being regulated in the provisions of Article 1 of the UUPA $1960 .^{3}$

Based on the provisions of Article 33 paragraph 3 of the 1945 Constitution and Article 1 of the LoGA, then interpreted / interpreted authentically and the scope of understanding as stipulated in Article 2 paragraph 1, states that: "On the basis of the provisions in Article 33 paragraph 3 of the 1945 Constitution and things the matters referred to in Article 1, earth, water and space, including the natural resources contained therein at the highest level "controlled by the state" as an organization of power of the entire people ". ${ }^{4}$ General explanation of UUPA number II further explained that; "... it is not necessary and inaccurate that the Indonesian people or the State act as landowners, it is more appropriate if the state as an organization of power from all people (the nation) acts as the Ruling Body". As a law that is fully formulated in a neo-populist atmosphere, the statements contained in these general articles and explanations are truly appropriate.

\subsection{After UUPA 1960}

The development of theoretical thinking about the right to control the state in the period after the enactment of UUPA 1960, there are several thoughts represented, among others, namely:

- Boedi Harsono; argues that the right to check as the right of the people of Indonesia, this country is owned by the people of Indonesia. The right to master contains two elements; A) belonging to the private sector; b) the element of duty of authority; Organizing, planning and management, including public law. In addition, Boedi Harsono argued that the implementation of the duties of authorities to regulate, plan and manage the Indonesian state was delegated to the Indonesian population as an organizational force for all Indonesia ${ }^{5}$. The state authority in relation to the right to control, the state in its position as an organization of the strength of all people, in this context is the state which is then official as explained in the provisions of Article 2 paragraph 2, UUPA 1960 competent to:

a. Regulates and organizes the designation, use, supply and maintenance of the water and space earth;

b. determine and regulate legal relations between people and earth, water and space;

c. determine and regulate legal relations between people and legal actions concerning the earth, water and space.

Based on the authority stipulated in Article 2 paragraph 2, the right to control by the state over the earth, water and space includes rights, both those that have been controlled by a person and those who have not been controlled. Furthermore, it was explained that state power over land that is owned by someone with a right, is limited by that right, meaning that to what extent the state gives power to those who have it to use it, until that is where the state's power. ${ }^{6}$

Still in the context of the right to control the country, Gouw Giok Siong also argues that the state is more appropriately seen as an organization of power of all people (nations), therefore it is not necessary for the state to work with the understanding of property as well as domestic theory. ${ }^{7}$

- Achmad Sodiki; the delegation does not include the element of belonging, but is limited to elements of a public legal nature. So land in the territory of the Republic of Indonesia is the land belonging to the Indonesian people, the land belongs to the people of Indonesia and not the property of the country. ${ }^{8}$ Based on such constructs of thought, the state can grant land rights to individuals as officers of the Indonesian Nation, to be used for the interests concerned. On the other hand the state can also accept land from individuals because of

\footnotetext{
${ }^{1}$ Subekti Mahanani, Kedudukan UUPA dan Pengelolaan Sumber Daya Agraria di Tengah Kapitalisme Negara (Politik Kebijakan Hukum Agraria Melanggengkan Ketidakadilan), Jurnal Sosial, Vol.6 No.2 Juli 2001, P.23. dijelaskan bahwa hak menguasai negara pasca kolonial untuk pertama kali diwakili oleh Pasal 33 ayat 3 UUD 1945 dan UUPA.

${ }^{2}$ Ronald Z. Titahelu, (1993), Penetapan Azas-Azas Hukum Umum Dalam Penggunaan Tanah Untuk Sebesar-Besarnya Kemakmuran Rakyat (Kajian Filsafati dan Teoritik Tentang Pengaturan dan Penggunaan Tanah di Indonesia, Desertasi Tidak Diterbitkan, P .2.

${ }^{3}$ Boedi Harsono, Menuju Penyempurnaan.......... Op.cit, P. 45

${ }^{4}$ Achmad Sodiki, Penataan,. Loc.Cit.

${ }^{5}$ Boedi Harsono, (1983), Penggunaan dan Penerapan Azas-Azas Hukum Adat pada Hak Milik Atas Tanah, Makalah Simposium Hak Milik atas Tanah, Bandung, P. 4.

${ }^{6}$ Ibid., compare with Endang Sukendar dan Ifdal Kasim, .......Op., Cit. P. 23.

${ }^{7}$ Imam Sutiknyo, (1987), Proses Terjadinya UUPA; Peran Serta Seksi Agraria Universitas Gajah Mada, Gajah Mada University Press, P. 121.

${ }^{8}$ Achmad Sodiki, (1993), Penataan.............. Op.cit, hal. 34.
} 
surrender or due to statutory provisions. By accepting delegation in the field of public law, the state has the right to take actions which regulate legal relations, both concrete actions and implementation of designation, use, supply and maintenance of the earth, water and space. ${ }^{1}$

The implementation of the right to control by this country, part of its authority can also be given by assigning to regions in the context of medebewind and to central officials in the region in the framework of deconcentration. ${ }^{2}$ In addition, the implementation of some of the authorities originating from the control of the state can also be delegated to departments, non-departmental government agencies, customary law communities, certain legal entities, namely management rights. The right to control by this country also includes land in forest areas, mining, transmigration, public works and other land which is controlled by other parties even with property rights. Based on this description, the right to control by the state can be limited by customary rights, management rights, waqf and other land rights without negating its existence, as long as the limitation of these rights comes from the state's right of control and is limited by the existence of the rights concerned. ${ }^{3}$

- Sri Hajati, a discussion on the right to control land by the state for the future, was proposed by Sri Hajati through his dissertation as stated; Therefore, the right to control the state is strictly limited in the future and it is time to think of alternatives to the right to control the country so that rights can be limited in conception and implementation. ${ }^{4}$ This state authority limitation is regulated in General Explanation Number II number 2 UUPA 1960, namely; state power regarding the land that is owned by a person with a right (land of rights), limited by the contents of that right. That is, to what extent the State gives power (authority) to those who have the right to exercise their rights, that is where the boundary of state power is. Whereas the plots of land which are not controlled by these rights are directly controlled by the state and are called "State Land".

\section{Conclusion}

Based on the description above, it can be concluded, as follows:

1) Mastery that prevails in traditional Javanese kingdoms, there is a system of land tenure according to customary law. The concept of land tenure in this system is based on communal rights, namely the rights of the legal community as a unit that has the authority to tie it in and out.

2) In accordance with the political developments in Netherlands in 1870 which switched to liberal politics, the Wet Agrarische 1870 was issued (Staatblad No.55, 1870) on April 9, 1870 and was completed with the regulation on the implementation of the Extraordinary Agreement namely Agrarische Besluit (Staatblad No.118, 1870). This AB only applies in Java and Madura, then the original dominance statement also only applies in Java and Madura. Article 1 AB regulates important provisions, namely; "Domeinverklaring" (domein statement) which states that: "By not reducing the entry into force of the provisions in paragraphs 2 and 3 of Agrarische Wet. So it is maintained as a principle, that "all land that other people cannot prove, that the land is its eigendom land, is the domain of the country".

3) After the period of independence of the development of ideas about the right to control the state, it has been pursued as stated in Article 33 paragraph 3 of the 1945 Constitution, which has shown that; 1) The state controls the earth, water and natural resources contained therein; 2) The earth, water and natural resources contained therein are used for the greatest prosperity of the people.Based on this formula, it has given instructions on how to think (denken), will (willen), and act or act (hendelsen) above; earth, water and natural resources contained in it. This is where the right of control by the state is located as an ideology of work (idealized working), a basic guideline and at the same time a program that is applied in various laws.Based on this formula, it has given instructions on how to think (denken), will (willen), and act or act (hendelsen) above; earth, water and natural resources contained in it. This is where the right of control by the state is located as an ideology of work (idealized working), a basic guideline and at the same time a program that is applied in various laws. Declaration of the rights of the nation as the highest tenure right over common land, is at the same time a parent for other tenure rights over land, finally obtained arrangements in the provisions of Article 1 of the UUPA 1960. Based on the provisions of article 33 paragraph 3 of the 1945 Constitution and Article 1 of the UUPA, then interpreted/interpreted authentically and the scope of understanding as stipulated in Article 2 paragraph 1 which states that: "On the basis of the provisions in Article 33 paragraph 3 of the Basic Law and the matters referred to in Article 1, earth, water and space, including the natural resources contained in it at the highest level "controlled by the state" as an organization of power of the entire people ".

\footnotetext{
${ }^{1}$ Ibid.

${ }^{2}$ Boedi Harsono, Nenuju Penyempurnaan ....... Op.cit, P. 52.

${ }^{3}$ Ibid, . P. 54.

${ }^{4}$ Sri Hajati, (2003), Pengaturan Hak AtasTanah dalam Kaitannya dengan Investasi, Disertasi, Universitas Airlangga, (Tidak diterbitkan), Surabaya, P. xii-xiii.

${ }_{5}^{5}$ Muhammad Bakri, (2007), Hak Menguasai Tanah Oleh Negara (Paradigma Baru Untuk Reformasi Agraria, Citra Media, Yogyakarta, P. 252.
} 


\section{References}

Books

Bakri, Muhamad, 2007, Hak Menguasai Tanah Oleh Negara (Paradigma Baru Untuk Reformasi Agraria), Citra Media, Yogyakarta.

Harsono, Boedi, 1986, Hukum Agraria Indonesia,Himpunan Peraturan- Peraturan Hukum Tanah, Djambatan, Jakarta.

--------, 1993, Penggunaan dan Penerapan Azas-Azas Hukum Adat Pada Hak Milik Atas Tanah, Makalah Pada Simposium Hak Milik Atas Tanah, Bandung.

-------, 1995, Hukum Agraria Indonesia (Sejarah Pembentukannya Undang-Undang Pokok Agraria dan Pelaksanaannya, Djambatan, Jakarta.

-------, 2003, Menuju Penyempurnaan Hukum Tanah Nasional, Dalam Hubungannya Dengan TAP MPR RI IX/MPR/2001, Penerbit Usakti, Jakarta.

-------, 1983, Penggunaan dan Penerapan Azas-Azas Hukum Adat Pada Hak Milik Atas Tanah, Makalah Pada Simposium Hak Milik Atas Tanah, Bandung.

Himawan, Charles, 1987, The Role of Law in Indonesia's Plantation Invesment, Paper Presented at "Solely to be used During the $3^{\text {rd }}$ Meeting of Joint Working Party Between Indonesia and United Kingdom, Oktober $7^{\text {th }}$ 1981, Jakarta.

Hajati, Sri, 2003, Pengaturan Hak AtasTanah dalam Kaitannya dengan Investasi, Disertasi, Airlangga University, (Tidak diterbitkan), Surabaya.

Kartodirdjo, Sartono, 1987, Pengantar Sejarah Indonesia Baru; Sejarah Pergerakan Nasional, Pt. Gramedia, Jakarta. Mahfud, MD, 1999, Karakter Produk Hukum Zaman Kolonial (Studi Tentang Politik dan Karakter Produk Hukum Pada Zaman Penjajahan di Indonesia), UII Press, Yogyakarta.

Mahanani, Subekti, 2001, Kedudukan UUPA dan Pengelolaan Sumber Daya Agraria di Tengah Kapitalisme Negara (Politik Kebijakan Hukum Agraria Melanggengkan Ketidakadilan), Jurnal Sosial, Vol. 6 No. 2 Juli 2001.

Notonagoro, 1964, Politik Hukum dan Pembangunan Agraria di Indonesia, Bina Aksara, Jakarta.

Onghokham, 1984, Perubahan Sosial di Madiun Selama Abad XIX: Pajak dan Pengaruhnya Terhadap Penguasaan Tanah (Dalam Dua Abad Penguasaan Tanah; Pola Penguasaan Tanah di Jawa dari Masa ke Masa), PT. Gramedia, Jakarta.

Rajagukguk, Erman, (1995), Hukum Agraria, Pola Penguasaan Tanah dan Kebutuhan Hidup, Chandra Pratama, Jakarta.

R. Van Dijk, (terjemahan) Suhardi 1964, Pengantar Hukum Adat Indonesia, Bandung.

Sodiki, Achmad, 1994, Penataan Pemilikan Hak Atas Tanah Di Daerah Perkebunan Kabupaten Malang (Studi tentang Dinamika Hukum), Desertasi, Tidak diterbitkan, Malang.

Soehino, 1986, Ilmu Negara, Liberty, Yogyakarta.

Subadi, (2002), Implementasi Hukum dan Kebijakan Penataan Ruang Dalam Pembangunan Perumahan Berwawasan Lingkungan Berkelanjutan di Kota Madiun, Tesis, Tidak Diterbitkan, Malang.

Sutiknyo, Imam, 1987, Proses Terjadinya UUPA, Gajah Mada University Press, Yogyakarta.

Titahelu, Ronald Z., 1993,Penetapan Azas-Azas Hukum Umum Dalam Penggunaan Tanah Untuk SebesarBesarnya Kemakmuran Rakyat (Kajian Filsafati dan Teoritik Tentang Pengaturan dan Penggunaan Tanah di Indonesia, Desertasi Tidak Diterbitkan, Airlangga University, Surabaya.

Wignjosoebroto, Soetandyo, 1995, Dari Hukum Kolonial ke Hukum Nasional (Dinamika Sosial Politik Dalam Perkembangan Hukum Di Indonesia), Raja Grafindo Persada, Jakarta.

\section{Regulations:}

1. Undang-Undang Dasar Negara Republik Indonesia Tahun 1945.

2. Undang-Undang Nomor 5 Tahun 1960 tentangPeraturan Dasar Pokok-Pokok Agraria.

3. Undang-Undang Nomor 11 Tahun 1967 tentang Pertambangan.

4. Undang-Undang Nomor 11 Tahun 1974 tentang Pengairan.

5. Undang-Undang Nomor 9 Tahun 1985 tentang Perikanan

6. Undang-Undang Nomor 5 Tahun 1990 tentang BKSDA.

7. Undang-Undang 22 Tahun 2001 tentang Minyak dan Gas.

8. Undang-Undang Nomor 26 Tahun 2007 Tentang Penataan Ruang. 